\title{
Sistem Informasi Inventori Gudang Untuk Mengontrol Persediaan Barang Pada Gudang Studi Kasus : PT.Alaisys Sidoarjo
}

\author{
Hendra Agusvianto \\ Program Studi S2 Pendidikan Teknologi dan Kejuruan, Universitas Negeri Surabaya \\ agusviantoh@gmail.com
}

\begin{abstract}
Abstrak- Sebagai perusahaan Tknologi distributor, PT.Alaisys selalu melakukan pengawasan dan Percatatan terhadap barang persedian. Pelaporan dari gudang ke kantor pusat di lakukan dengan cara menyalindata dari kartu ke dalam microsof office excel. Laporan dalam format excel tersebut harus di kirim via email atau Gadget. Sistem tersebut menjadikan pihak kantor pusat tidak dapat mengetahui data dari gudang dengan efisien. Dari permasalahan tersebut di atas, PT.Alaisys memerlukan adanya aplikasi aplikasi sistem inventory gudang berbasis web. Aplikasi dapat di gunakan dalam mengiventariskan produk yang ada pada stok stok di gudang yang meliputi pencatatan, pengolahan, dan pelaporan data data pada persediaan gudang. Dengan adanya Aplikasi berbasis web, kantor pusat dapat melihat laporan dari gudang dengan tepat sasaran, akurat, dan efisien. Kata Kunci: Sistem Informasi Inventory, Web Sistem Informasi, PHP, dan DFD
\end{abstract}

\section{I.PENDAHULUAN}

Perkembangan teknologi yang sangat pesat di era globalisasi saat ini telah memberikan banyak manfaat dalam kemajuan diberbagai aspek sosial. Penggunaan teknologi oleh manusia dalam membantu menyelesaikan pekerjaan merupakan hal yang menjadi keharusan dalam kehidupan. Perkembangan teknologi ini juga harus diikuti dengan perkembangan pada Sumber Daya Manusia (SDM).

Manusia sebagai pengguna teknologi yang harus mampu memanfaatkan teknologi yang ada saat saat ini, maupun perkembangan teknologi tersebut selanjutnya. Adaptasi manusia dengan teknologi baru yang telah berkembang wajib untuk dilakukan melalui pendidikan. Hal ini dilakukan agar generasi penerus tidak tertinggal dalam hal teknologi baru. Dengan, teknologi dan pendidikan mampu berkembang bersama seiring dengan adanya generasi baru sebagai penerus generasi yang lama. Beberapa cara adaptasi tersebut dapat diwujudkan dalam bentuk Sistem Informasi Inventory.

PT.Alaisys yang didirikan pada tahun 2010. Yang bergerak di bidang usaha perdagangan, peridustrian, jasa, Di bidang perdagangan yang meliputi import dan perdagangan pada peralatan peralatan peralatan pada bagian multimedia, listrik, elektronik, distributor, agen dan sebagai perwakilan dari badan badan perusahaan. Di Bidang perindustrian yang meliputi berbagai macam industri antara lain alat ukur dan perakitan komputer. Di bidang jasa antara lain jasa instalasi dan perawatan pada maintenance komputer. Perusahan ini berkantor pusat di surabaya, mempunyai gudang di sidoarjo dan memiliki kantor cabang di jakarta. Kantor pusat yang bertempat di J1.Raya Kalirungkut 5 Blok E-38 Rungkut Mega Raya di Surabaya, Jawa Timur. PT.Alaisys memilki beberapa bagian staf, yaitu bagian bagian bagian keuangan, akuntansi, marketing, IT, personalia menempati kantor kantor pusat pusat di surabaya. Pergudangan PT.Alaisys bertempat di jalan tambak sawah, Blok A pada no 18, Waru Sidoarjo. Sebagai perusahaan di bidang distributor, PT.Alaisys selalu melakukan pengawasan dan pencatatan terhadap barang persediaan. Pengolahan data data gudang pada PT.Alaisys sampai saat ini masih manual seperti pencatatan informasi pada penjualan dan persediaan barang dengan menggunakan bon nota buku pencatatan dan laporan yang semua masihdi tulis tangan. Untuk mendapatkan data yang dibutuhkan harus mencari satu persatu nota yang telah di simpan Maka dengan di bangun aplikasi aplikasi sistem inventori gudang berbasis web yang digunakan pada PT.Alaisys diharapkan dapat memberi solusi solusi dalam hak akses, Pencatatan pengolahan pada data barang sehingga dapat meningkatkan efektifitas perusahaan.Memudahkan karyawan dalam melakukan bagian pengontrolan persediaan barang.

1) Menyediakan informasi infomasi yang cepat, tepat dan akurat menegani data maupun laporan.

2) Memudahkan proses di penyampaiannya laporan informasi ke kantor pusat.

\section{II.TINJAUAN PUSTAKA}

\section{A. Flowchart}

Flowchart atau Bagan alir adalah bagan (chart) yang menunjukkan alir alir (flow) di dalam program atau prosedur sistem secara logika. Bagan alir (flowchart) yang digunakan terutama untuk alat alat bantu di komunikasi dan untuk dokumentasi.

Jenis jenis Flowchart

Ada beberapa jenis flowchart diantaranya:

- Bagan alir sistem (systems flowchart).

- Bagan pada alir dokumen (document flowchart).

- Bagan pada alir skematik (schematic flowchart).

- $\quad$ Bagan pada alir program (program flowchart).

B. $D F D$ 
Data Flow Diagram (DFD) ini merupakan suatu cara atau metode untuk membuat rancangan sebuah sistem yang mana berorientasi pada alur data yang bergerak pada sebuah sistem nantinya. Dalam pembuatan pada Sistem Informasi, DFD sering digunakan. DFD dibuat oleh para analis untuk membuat sebuah sistem yang baik. Dimana DFD ini nantinya diberikan kepada para programmer untuk melakukan proses coding. Dimana para programmer melakukansebuah coding sesuai dengan DFD yang dibuat oleh para analis sebelumnya. Tools yang digunakan pada pembuatan DFD (Data Flow Diagram) yaitu Power Designer 16.

Salah satu cara lain untuk mendesain sistem yaitu menggunakan Microsof Office Viso 2010.

\section{C. $P H P$}

PHP adalah bahasa pemrograman script server-side yang didesain untuk pengembangan web. Selain itu, PHP juga bisa digunakan sebagai bahasa pemrograman pemrograman umum. PHP di kembangkan pada tahun 1995 oleh Rasmus Lerdorf, dan sekarang dikelola oleh The PHP Group. Situs situs resmi PHP beralamat di http://www.php.net. PHP disebut bahasa bahasa pemrograman server side karena PHP diproses pada komputer server. Hal ini berbeda dibandingkan dengan bahasa pemrograman client-side seperti JavaScript yang diproses pada web browser (client).

\section{Mysql}

MySQL adalah sebuah implementasi dari sistem sistem manajemen yang pada basis basis data yang relasional (RDBMS) yangdidistribusikan secara gratis. Setiap setiap pengguna dapat secara bebas menggunakan MySQL, namun dengan batasan perangkat lunak tersebut tidak boleh dijadikan produk turunan yang bersifat komersial. MySQL sebenarnya merupakan turunan salah satu konsep utama dalam basis basis dan data data yang telah ada sebelumnya; SQL (Structured Query Language). SQL adalah sebuah inti konsep pengoperasian basis data, terutama untuk pemilihan atau seleksi dan pemasukan data data, yang memungkinkan pada pengoperasian data dikerjakan dengan mudah secara otomatis.

\section{E. Sistem Informasi}

Sistem informasi adalah suatu sistem yang di dalam terdapat suatu organisasi yaitu yang mempertemukan kebutuhannya pada pengolahan transaksi harian yang mendukung fungsi funsgsi operasi organisasi yang bersifat manajerial dengan kegiatan strategi dari suatu organisasi dan untuk dapat menyediakan kepada pihak luar tertentu dengan laporanlaporan yang diperlukan.

Manfaat adanya sistem informasi dalam suatu instansi yaitu:

1) Menyajikan suatu pusat informasi guna yaitu mendukung pengambilan suatu keputusan.

2) Menyajikan informasi yang guna mendukung operasi harian.

3) Menyajikan sebuah informasi yang berkenaan dengan kepengurusan.
Beberapa komponen pada sistem informasi yang dapat diklasifikasikan

sebagai :

1) Perangkat keras yaitu (hardware) dan perangkat lunak yaitu (software) yang berfungsi sebagai mesin.

2) Manusia (people) dan prosedur (procedures) yang merupakan manusia dan tata caramenggunakan mesin.

3) Data merupakan jembatan penghubung antara manusia dan mesin agar terjadi suatu proses pengolahan data.

\section{F. Apache}

Apache adalah sebuah nama web server yang bertanggung jawab pada request-response HTTP dan logging informasi secara detail (kegunaan dasarnya). Selain itu, Apache juga diartikan sebagai suatu web web server yang kompak, modular, mengikuti standar protokol HTTP, dan tentu saja sangat digemari. Kesimpulan ini bisa didapatkan dari jumlah pengguna yang jauh melebihi para pesaingnya. Sesuai hasil survei yang dilakukan oleh Netcraft, bulan Januari 2005 saja jumlahnya tidak kurang dari 68\% pangsa web server yang berjalan di Internet. Ini berarti jika semua web server selain Apache digabung, masih belum bisa mengalahkan jumlah Apache.

\section{G. $H T M L$}

HTML ( Hypertext Markup Language ) adalah bahasa dasar untuk web scripting bersifat Client Client yang memungkinkan yaitu untuk menampilkan informasi dalam bentuk teks, grafik- grafik pada multimedia dan juga untuk menghubungkan antar tampilan web page atau yang lebih dikenal dengan Hyperlink. Tidak diperlukan suatu program editor khusus untuk menggunakan kode kode perintah HTML, kita dapat menggunakan Notepad, Edit Plus ataupun editor lainnya yang berbasis GUI

( Graphical User Interface ) seperti Microsoft Front Page, Dreamweaver CS3, Adobe Golive dan sebagainya, namun dengan program ini kita tidak perlu mengetik kode HTMLnya, semua perintah diwujudkan secara Icon Base. Sebagai seorang pada pengembang aplikasi web maka kemampuan penguasaan kode HTML sangat diperlukan, dengan demikian kita mampu menguasai program-program editor lainnya. Untuk dapat menguasai kode-kode pada HTML sangat disarankan menggunakan pada editor teks misalnya Notepad .

\section{H. Aplikasi Berbasis Web}

Yang dimaksud dengan aplikasi web atau aplikasi berbasis web adalah aplikasi yang dijalankan melalui browser. Aplikasi aplikasi seperti ini pertama kali dibangun hanya dengan menggunakan bahasa yang disebut dengan HTML (HyperText Markup Language) dan protokol yang digunakan dan dinamakan HTTP (HyperText Transfer Protokol). Namun, tentu saja hal hal seperti ini memiliki kelemahan. Semua perubahan harus dilakukan pada level aplikasi. Pada perkembangan berikutnya, sejumlah skrip dan objek 
dikembangkan untuk memperluas kemampuan HTML. Pada saat ini, banyak skrip seperti itu antara lain diantaranya yaitu PHP, ASP, ASP.NET sedangkan contoh yang berupa objek antara lain adalah applet (Java).

\section{Adobe Dreamwever}

Dreamweaver CS5 adalah salah satu HTML Editor editor profesional yang berfungsi untuk mendesain web secara visual dan mengelola situs atau halaman web. Berdasarkan definisidefinisi di atas ini, maka dapat di simpulkan dreamweaver adalah suatu aplikasi yang digunakan dalam membangun atau membuat sebuah web.

\section{Metodologi Penelitian}

\section{A. Metode Penelitian}

Pada Bab ini di jelaskan metodologi sistem informasi informasi yang akan digunakan untuk menyelesaikan peneltian langkah utama yang di lakukan yaitu, Studi literatur, kebutuhan sistem, analisa desain system system, Implementasi dan pengujian sistem. Berikut alur alur diagram peneltian. Analisa dan Definisi Kebutuhan Sistem
1) Studi Literatur
2) Observasi
3) Wawancara
4) Kuisioner
5) Identifikasi Dokumen

Analisa dan Desain Sistem
1) Flowchart
2) Contex Diagram
3) DFD Level O
4) DFD Level 1
5) DFD Level 2
6) Implementasi
7) Testing

\section{B. Kebutuhan Perangkat Keras}

Berikut ini merupakan spesifikasi perangkat keras yang dibutuhkan dalam menggunakan aplikasi ini:

1) Monitor

2) Keyboard

3) Mouse

4) Printer

5) $\mathrm{PC} /$ Laptop, dengan minimum spesifkasi
a. Processor Intel Core2duo
b. RAM 512 MB
c. Hard disk $80 \mathrm{~GB}$
d. VGA $128 \mathrm{MB}$

C. Kebutuhan Perangkat Lunak

Berikut ini merupakan spesifikasi perangkat lunak yang dibutuhkan dalam membangun aplikasi ini:
a. Sistem Operasi Windows XP
b. Macromedia Dreamweaver 8.0
c. Microsoft Office

d. Basis Data menggunakan MySQL

e. Browser seperti Mozilla Firefox atau Google Chrome

f. Power Desainer 16

g. Microsof Visio 2010

D. Perancangan Sistem

a. Flow Chart Diagram Alur

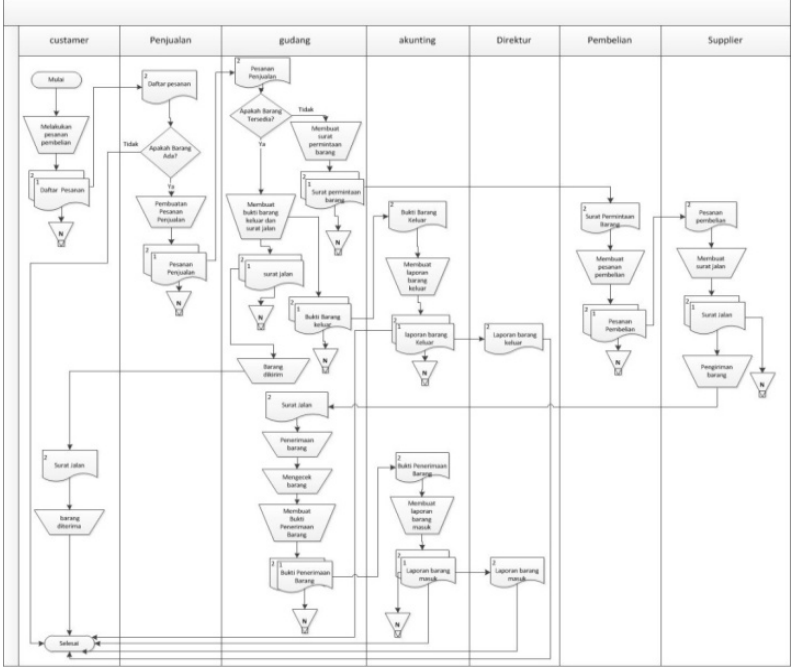

Gambar. 1 Flowchart Diagram Alur Sistem Informasi Inventori Gudang PT.Alaisys.

b. Contex Diagram

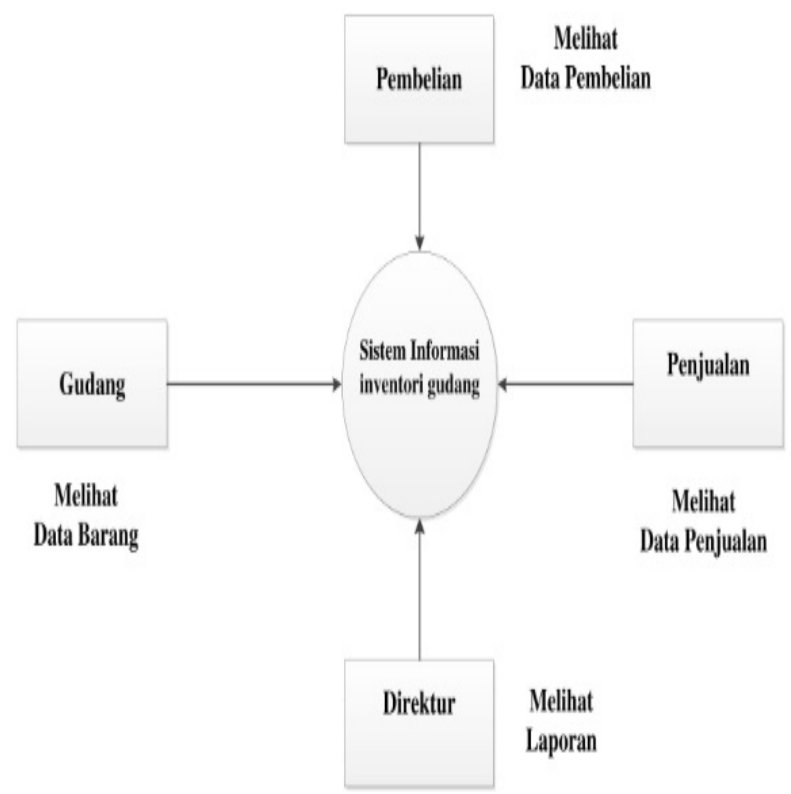

Gambar. 2 Flowchart Contex Diagram Sistem Informasi pada Inventori pada PT.Alisys

c. DFD Level 0 


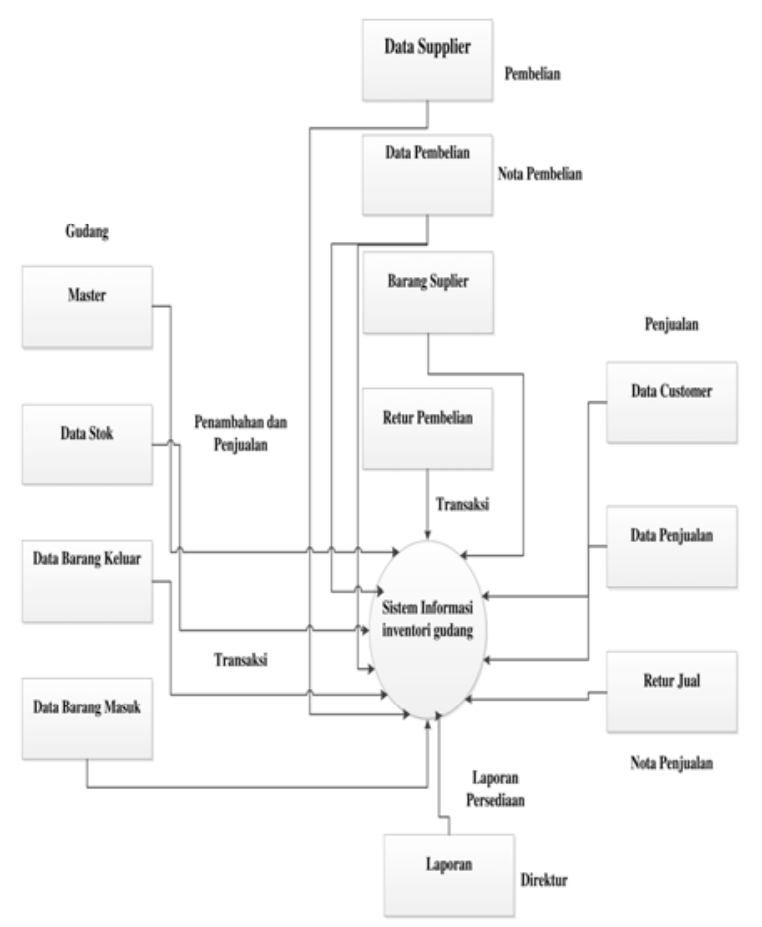

Gambar. 3 DFD Level 0 Sistem Inventori Gudang PT.Alaisys

d. DFD Level 1

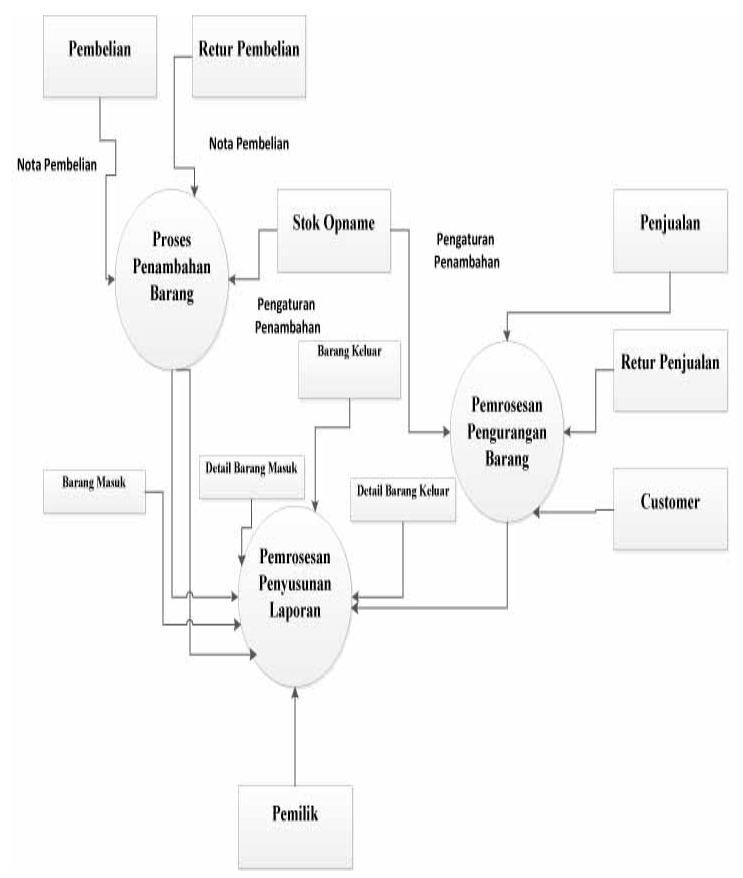

Gambar. 4 DFD Level 1 Sistem Inventori Gudang PT.Alaiys

\section{E. Proses Bisnis}

Proses bisnis Yang terjadi pada perusahaan PT.Alaisys seagai berikut :

1) Bagian Penjualan menerima dokumen daftar pesanan dari customer jika barang barang ada, bagian penjualan membuat dokumen pesanan penjualan.

2) Bagian gudang menerima dokumen pesanan penjualan dari bagian bagian penjualan, yaitu melakukan pencatatn barang keluar dan surat jalan, Jika barang tidak tersedia, bagian gudang membuat surat permintaan barang.

3) Bagian gudang menerima dokumen barang masuk dari suplier, melakukan pengecekan barang sesuai pencatatan barang masuk.

4) Bagian akunting menerima dokumen dokumen barang keluar dan barang masuk dari bagian satf gudang, membuat laporan barang keluar dan barang masuk.

5) Bagian pembelian menerima surat permintaan barang dari gudang, dan membuat pesanan pembelian.

6) Direktur utama menerima laporan barang masuk dan barang keluar dari bagian akunting.

\section{HASIL DAN ANALISA SISTEM INVENTORI GUDANG PT.ALAISYS}

\section{A. Hasil dan Analisa}

Hasil dan Analisa dari Sistem Inventori Gudang Pada PT.Alaisys adalah Sebagai Berikut:

Tabel I. Hasil dan Analisa

\begin{tabular}{|l|l|}
\hline Parameter & Hasil dan Analisa \\
\hline Tepat waktu & $\begin{array}{l}\text { Ketika penambahan stok gudang, staf staf, } \\
\text { bertugas menghitung dan mencatat jumlah } \\
\text { stock stock yang dimasukkan. Di Terbatasnya } \\
\text { waktu yang akan digunakan dalam } \\
\text { pencatatan tersebut pada sebagian jenis stock } \\
\text { barang yang tidak sesuainya jumlahnya. } \\
\text { Akibatnya yaitu terjadi ketidaksamaan pada }\end{array}$ \\
$\begin{array}{l}\text { jumlah jumlah stok barang dengan data yang } \\
\text { ada di Gudang. }\end{array}$ \\
\hline Akurat & $\begin{array}{l}\text { Masalah akurasi data, dalam hal ini data stok } \\
\text { barang di gudang masih kurang. }\end{array}$ \\
\hline Relevan & $\begin{array}{l}\text { Inti dari sistem baru yang akan dibuat adalah } \\
\text { untuk mempermudah pegawai di gudang } \\
\text { dalam memperoleh data stok stok barang, } \\
\text { maka informasi informasi yang dipublikasikan } \\
\text { ini pastilah sangat bermanfaat bagi yang } \\
\text { menerima, dalam hal ini dalam pengecekan } \\
\text { barang di gudang. }\end{array}$ \\
\hline
\end{tabular}

B. Pengujian 


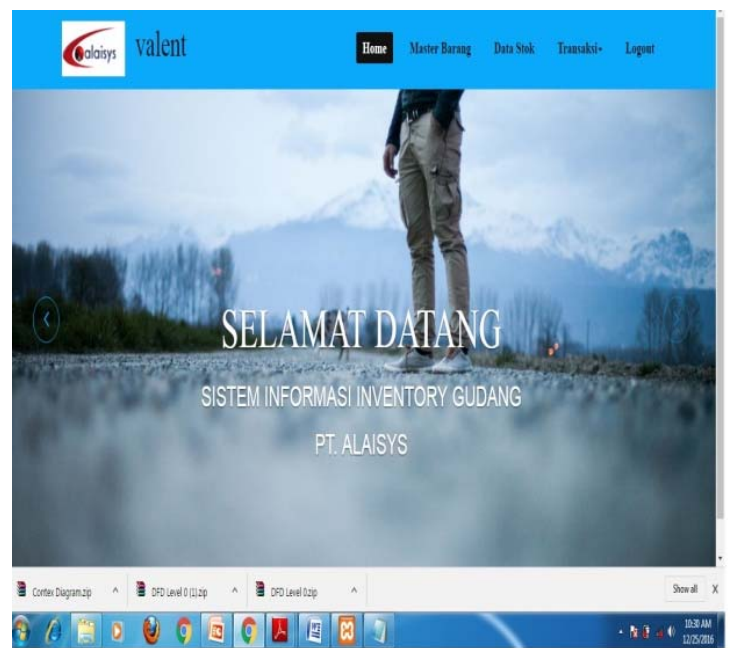

Gambar. 5 Halaman Home Sistem Informasi Inventori Gudang PT.Alaisys

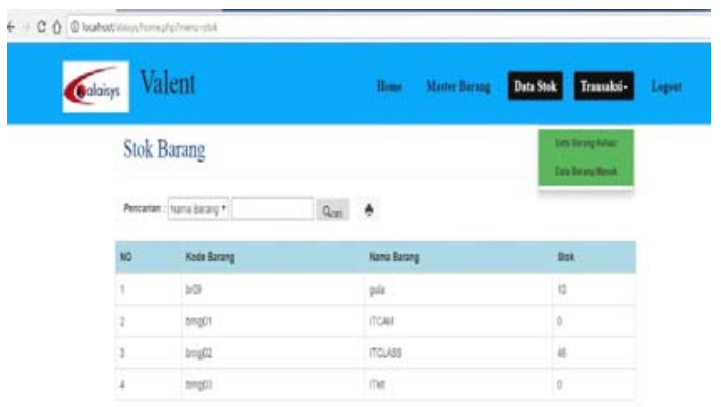

Gambar. 6 Halaman Stok Gudang PT.Alaisys

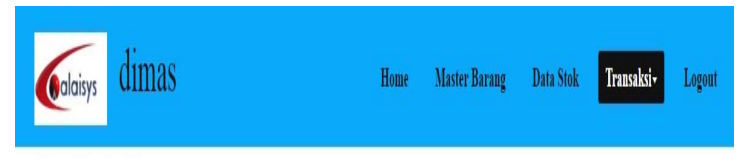

View Pemblian
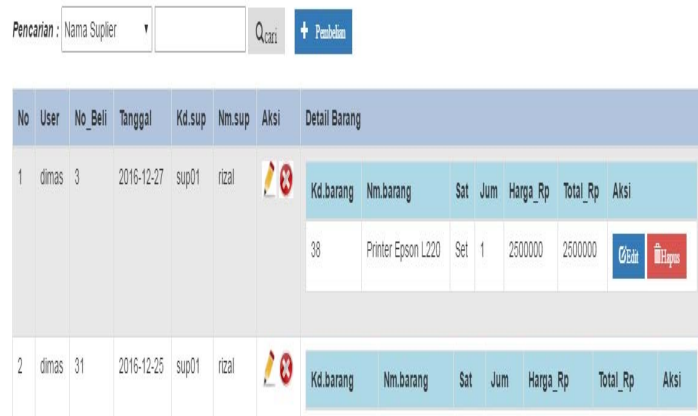

Gambar. 7 Halaman Data Pembelian PT.Alaisys

\section{B. Analisis Sistem}

Analisis sistem yang sedang berjalan merupakan kegiatan mempelajari interaksi sistem yang terdiri atas pelaku proses dalam sistem, prosedur dan data serta informasi yang terkait. Tujuan dari analisa sistem yang sedang berjalan adalah :

a.Menelusuri bagaimana sistem yang sedang

berjalan,dengan memperhatikan proses, flow map sistem yang berjalan, diagram kontek sistem yang berjalan, dan data flow diagram yang sedang berjalan.

b. Mengevaluasi sistem sehingga dapat mendukung dan meningkatkan kinerja sistem informasi yang akan dikembangkan.

c. Mendapatkan kemungkinan pengembangan sistem yaitu proses dan subproses yang dapat dimodifikasi kearah yang lebih baik atau akan lebih dimudahkan dengan sistem yang terotomatisasi.

\section{Analisis Dokumen}

Sistem Informasi Pengelolaan Pada Persediaan Barang merupakan perangkat lunak yang dikembangkan untuk membantu proses pembuatan laporan pemesanan di PT.AALYSYS yang berupa pembuatan laporan hasil pemesanan barang, pengelolan data barang sampai dengan laporan dan validasi login untuk admin dan bagian gudang. Aplikasi ini membantu Admin dan bag.gudang dalam mengetahui barang yang yang ada di gudang. Selain itu, sistem ini juga membantu dalam membuat pelaporan hasil pemesanan barang secara cepat dan akurat. Sebelum menggunakan aplikasi ini, pengguna wajib melakukan login untuk menjaga keamanan informasi dari halaman yang akan diakses.

\section{Analisis Prosedur yang sedang Berjalan}

Analisi prosedur yang sedang berjalan adalah bagian yang menjelaskan tentang data - data yang didapat dari perusahaan untuk pembangunan sistem informasi persediaan barang.

\section{E. Evaluasi Sistem Yang Berjalan}

Untuk memperbaiki sistem kerja maka perlu dilakukan identifikasi masalah. Adapun evaluasi terhadap sistem yang berjalan adalah sebagai berikut : Dibutuhkan suatu perangkat lunak untuk menangani sistem pengelolaan persediaan barang di gudang yang cepat dan akurat dalam memberikan informasi mengenai barang yang ada digudang dan bagaimana pengelolaan persediaan barang yang ada di PT ALAYSYS terbangun dengan maksimal.

\section{F. Perancangan Prosedur yang Diusulkan}

Rancangan yang diajukan kepada pihak perusahaan akan meliputi flow map,kamus data, diagram kontek, data flow diagram (DFD), Akan tetapi flow map, diagram kontek, 
dan data flow diagram (DFD) pada dasarnya sama seperti sistem yang sedang berjalan saat ini.Namun prosedur yang diusulkan oleh kami kepada perusahaan yaitu lebih terotomatisasi yang artinya proses penginputan data lebih efisien dan efektif guna mempercepat proses, serta lebih memudahkan dalam perancangan sebuah sistem informasi. Untuk perancangan sistem informasi yang diusulkan, masih mengikuti sistem informasi yang sudah berjalan. Hanya saja yaitu pada porses proses penginputan dan penyimpanan yang berbeda pada lebih terotomasisasi dan memberikan kemudahan dalam pengoperasian sistem informasi yang dibuat.

G. Evaluasi Terhadap sistem yang Diusulkan Sistem yang sedang berjalan saat ini telah diperbaiki dengan rancangan yang telah dibuat. Adapun evaluasi terhadap sistem yang dirancang adalah sebagai berikut :

1. Pengolahan data pada sistem yang dirancang sistem sudah sangat efektif dan sangat Memudahkan Dalam Pengoperasian Sistem Informasi.

2. Dapat memperkecil kesalahan dalam pengolahan data.

\section{H. Analisis Kinerja (Performance)}

Pada proses pencatatan data data bahan baku, mutiara, penjualan dan pembelian masih dilakukan secara manual. Manual dalam arti menggunaan buku tulis sebagai media pencatatan awal lalu mengetik kembali pada komputer dengan menggunakan Ms.Office yaitu sebagai software pengolahaan datanya. Pencatatan pada manual yang memang memerlukan waktu yang lama menyebabkan diperlukannya waktu waktu khusus untuk melakukan pencatatan dan tentu saja karyawan tidak dapat melakukan kegiatan yang lain, seperti memberikan pelayanan kepada pelanggan yang datang. Pada saat melakukan proses penghitungan atau rekap stok barang dibutuhkan waktu yang cukup lama sekitar 1-2 jam. Dari hasil analisis tersebut maka berikut gambaran sistem baru pada perusahaan.

\section{Analisis Ekonomi (Economic)}

Pengolahan data yang masih dilakukan secara manual dapat menyebabkan informasi yang disajikan tidak akurat, terutama mengenai stok barang barang. Dan membuat penghasilan perusahaan menjadi berkurang karena informasi yang diberikan salah. Pencatatan penjualan dan pembuatan nota yang dilakukan secara manual dapat saja menimbulkan kecurangan, baik dari sisi konsumen maupun dari sisi karyawan.

\section{J. Analisis Pengendalian (Control)}

Dengan sistem pencatatan data yang manual, maka control terhadap bahan baku sampai dibutuhkan ketelitian dan perhatian yang sangat tinggi. Hal ini disebabkan sulitnya mencocokkan data stok yang tersedia saat itu sebelum dan setelah transaksi. Tidak adanya proteksi data, sehingga sering terjadi kehilangan data. Ditambah dengan catatancatatan transaksi dan stok yang terpisah membuat control barang menjadi semakin rumit.

\section{Analisis Efisiensi (Eficiency)}

Karyawan yang ada tidak dapat melayani pelanggan yang jumlahnya lebih dari satu. Satu karyawan hanya bisa melayani satu pelanggan. Dari proses pancarian mutiara di tempat penyimpanan, konsultasi/Tanya jawab sampai pada proses proses transaksi penjualan, dan seluruh tahapan itu bisa memakan waktu hingga 1 jam.

\section{Kesimpulan dan Saran}

Perancangan Sistem Informasi persediaan barang di bagian PT.ALAYSYS Sidoarjo merupakan perancangan dari system yang sedang berjalan. Berbagai permasalahan yang muncul telah diupayakan untuk dapat ditangani dengan system yang baru ini.

\section{A. Kesimpulan}

Berdasarkan uraian yang telah di jelaskan pada bab bab sebelumnya maka dapat disimpulkan bahwa :

1. Sistem ini merupakan suatu aplikasi system inventori pada gudang yang berfungsi untuk pencatatan keluar masuk barang oleh staf PT.Alaisys dapat dilakukan dengan struktur sehingga dapat memberikan bantuan dalam hal efisiensi waktu kegiatan pencatatan dan penyusunan data pada barang.

2. Dengan adanya aplikasi berbasis web ini dapat memberikan laporan pada pengolahan data barang dari gudang ke kantor pusat secara tepat, akurat dan tepat sasaran.

3. Sistem informasi manajemen yang diusulkan untuk perusahaan yaitu dengan melakukan pemisahan bagian pekerjaan yang pada sistem awal semua dilakukan secara sentralistik yaitu oleh sang pemilik perusahaan kini menjadi 4 bagian bagian yaitu bagian penjualan, pada bagian pembayaran (kasir)

B. Saran

Penulis menyadari bahwa pada Sistem informasi manajemen dan tata letak yang diusulkan ini masih memiliki beberapa kekurangan, untuk itu, apabila penelitian ini ingin dilanjutkan, penulis ingin memberi beberapa saran mengenai bagianbagian yang sebaiknya dibahas.

Sistem informasi Inventori gudang berbasis web ini masih banyak kekurangan dan kelemahan. Adapun saran atau masukan yang dapat penelitian berikan untuk menunjang atau pengembangan pengembangan pada sistem selanjutnya.sebagai berikut : 
1. Perubahan dan penambahan sistem baik dari segi fungsional maupun interface yang dapat di lakukan sehingga sistem terlihat lebih dinamis dan handal.

2. Melakukan pengembangan sistem sistem ini dapat menghitung laba rugi Karena pembuatan system ini hanya pada perhitungan persediaan barang.

3. Masalah koneksi koneksi jaringan komputerisasi dan software program program komputerisasi yang akan digunakan, tujuan tujuan yaitu memperhitungkan resiko trouble error yang mungkin terjadi pada sistem jaringan yang ada.

4. Masalah penentuan jumlah kebutuhan sumber daya di bagian penjualan dan kasir. Dalam hubungan dengan antrian pembeli yang terjadi saat sistem sudah berjalan.

5. Masalah pengelolaan sumber daya manusia yang berhubungan dengan rekrutmen rekrutmen, supervisi dan pelatihan yang perlu dilakukan oleh perusahaa

\section{REFERENSI}

[1] Kendall, Kenneth E., dan Kendall, Julie .2003. Analisis dan Perancangan Sistem Jilid 1.Jakarta: PT Prenhallindo.

[2] Makridakis. Wheelwright and McGee. 1993.Edisi pada metode versi Kedua. Metodedan Aplikasi Peramalan. Erlangga. Jakarta.Martiningtyas, Nining. 2004.

[3] Spyros, Makrindakis, Whell Wright, StevenC., Mcgee Victor E Alih bahasa: Untung SusAndriyanto, Abdul Basith. 1993. Metode danAplikasi Peramalan Edisi Kedua, Jakarta: Penerbit Erlangga

[4] Wibowo, Andi Agung., 2005, Rancang bangun Aplikasi Sistem Penerimaan Pesanan barang barang Dan Peramalan Peramalan Penjualan Dengan Metode Aplikasi Single Moving Average (Studi Kasus Perusahaan PT Kuat Bersaudara),Surabaya:STIKOMSurabaya

[5] Indrajan, S.kom., MM, 2011 Bedah Kilat 1 jam: Pengantar dan sistem basis data,Jakarta: PT alex media komputindo.

[6] Kadir.Abdul.2003.Pengenalan Sistem Informasi. Yogyakarta: Andi Offset.

[7] Kusrini. 2007. Strategi Perancangan dan Pengelolaan Basis Data. Yogyakarta: Andi Offset.

[8] Simarmata, Janner dkk.2006. Basis Data, Yogyakarta: Andi Offset.

[9] Sunyoto, Andi. 2007. Pemrograman Database dengan Visual Basic dan Microsoft SQL. Yogyakarta: Andi Offset. 